\title{
Breastfeeding and the risk of early childhood caries
}

\author{
Valerie White \\ Department of Public Health, NHS Fife and NHS Lothian, Cameron Hospital, Fife, Scotland
}

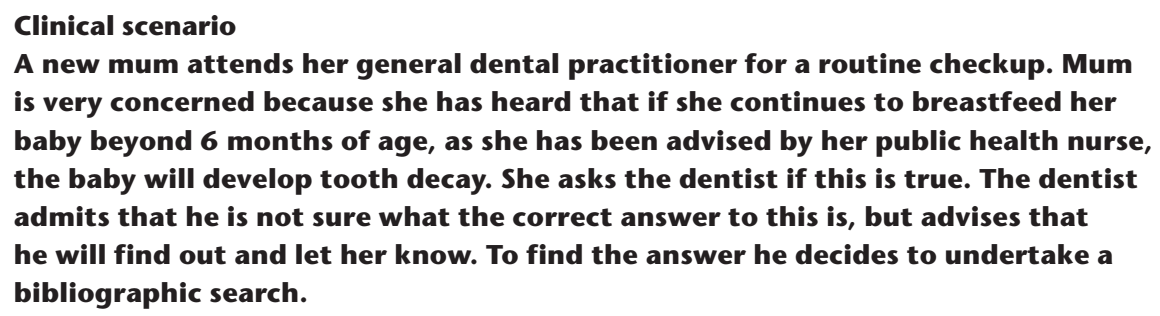

A new mum attends her general dental practitioner for a routine checkup. Mum is very concerned because she has heard that if she continues to breastfeed her baby beyond 6 months of age, as she has been advised by her public health nurse, the baby will develop tooth decay. She asks the dentist if this is true. The dentist admits that he is not sure what the correct answer to this is, but advises that he will find out and let her know. To find the answer he decides to undertake a bibliographic search.

\section{Clinical question}

The PICO (population-intervention-comparison-outcome) question developed was: does continuation of breastfeeding (intervention) increase the risk of early childhood caries (ECC; outcome) in infants of over 6 months of age (population), compared with other methods of infant feeding (comparison)?

\section{Search strategy}

The databases Medline (1996-2008), Embase (1996-2008) and CINAHL (19822008) were searched using OVID, along with all evidence-based medicine journals within OVID, PubMed and Trip Database (www.tripdatabase.com). The OVID search (see Table 1) used the following search terms: "breastfeeding" or "infant feeding" and "dental caries" or "oral health". Studies were limited to human subjects and English language and review articles (where possible). The OVID search identified 30 studies of which four were considered relevant. The PubMed and Trip database searches used similar search terms with only the PubMed search identifying an additional study. Details of the papers are summarised in Table 2.

\section{Discussion}

There have been reports in the literature that prolonged and on-demand breastfeeding is a potential risk factor for the development of ECC. ${ }^{5}$ Reliance on this evidence has, in some cases, led to dental professionals issuing advice regarding cessation of breastfeeding at 6 months. This bibliographic search identified five relevant articles on this topic, all of which failed to find an association between breastfeeding and development of ECC. Both review articles, however, highlight the poor quality of studies available on this topic. ${ }^{1,2}$ In particular, studies lack clarity and consistency in the definitions of breastfeeding patterns, ie, whether it is exclusive, ondemand, or at night. Inconsistency in the definitions of ECC also creates problems in comparability of studies. The review by Valaitis et al. ${ }^{1}$ which undertook systematic quality assessments of articles and would therefore be considered the more robust of the two reviews, concludes that, "the available evidence does not support a consistent and strong association between breastfeeding and development of ECC". The review does not include any randomised controlled trials (RCT), but it could be argued that a RCT is neither appropriate or ethical in this area. The RCT reported by Vitolo et al. ${ }^{3}$ and Kramer and colleagues ${ }^{5}$ are in fact sec- ondary analyses of RCT of the promotion of healthy infant feeding interventions. This, together with other methodological issues highlighted in Table 2 , suggests that the results and conclusions of these studies should be interpreted with caution.

The study undertaken by Iida et al..$^{5}$ does appear to take us a step further forward in answering the question of duration of breastfeeding and increased risk of ECC. Although this study's initial analysis suggested that children breastfed for $>1$ year in total were more likely to experience ECC than children who were breastfed for $<1$ year, the subsequent analysis (which controlled for confounding factors such as poverty, ethnicity and maternal smoking) demonstrated that there was no evidence that breastfeeding or its duration was associated with increased ECC. Unfortunately, the study was not able to explore the implications of other potential confounding factors such as oral hygiene practices and exposure to fluoride, but it does highlight that there are several other — and possibly more important - factors affecting development of ECC besides breastfeeding.

Breastfeeding has been found to have many health benefits for both the child, including protection against gastrointestinal infection, otitis media and necrotising enterocolitis, ${ }^{7}$ and mother, including delayed return of

\begin{tabular}{l|l|r}
\multicolumn{2}{l}{ Table 1. Search strategy } & Result (N) \\
\hline Search & Search term & 13207 \\
\hline 1 & breastfeeding.mp. [mp=ti, ot, ab, nm, hw, tx, kw, ct, sh, it, tn, dm, mf] & 5836 \\
\hline 2 & infant feeding.mp. [mp=ti, ot, ab, nm, hw, tx, kw, ct, sh, it, tn, dm, mf] & 16011 \\
\hline 3 & dental caries.mp. [mp=ti, ot, ab, nm, hw, tx, kw, ct, sh, it, tn, dm, mf] & 10398 \\
\hline 4 & oral health.mp. [mp=ti, ot, ab, nm, hw, tx, kw, ct, sh, it, tn, dm, mf] & 17490 \\
\hline 5 & 1 or 2 & 23666 \\
\hline 6 & 3 or 4 & 109 \\
\hline 7 & 5 and 6 & 30 \\
\hline
\end{tabular}


Table 2. Summary or relevant papers

\begin{tabular}{|c|c|c|c|c|}
\hline Paper & Study details & Key results & Conclusion & Study weaknesses \\
\hline $\begin{array}{l}\text { Valaitis et } \\
\text { al. }(2000)^{1}\end{array}$ & $\begin{array}{l}\text { Systematic review of } \\
\text { relationship between } \\
\text { breast feeding and ECC. } \\
\text { Modified Cochrane } \\
\text { Collaboration review } \\
\text { methodology: robust } \\
\text { systematic quality } \\
\text { assessment undertaken }\end{array}$ & $\begin{array}{l}28 \text { relevant articles identified ( } 86 \% \\
\text { case-control; } 11 \% \text { case series } \\
\text { approach; } 4 \% \text { cross-sectional). } \\
\text { Quality assessed as strong }=0 ; \\
\text { moderate }=11 \% ; \text { weak }=32 \% \text {; very } \\
\text { weak }=57 \% . \text { Overall quality of studies } \\
\text { poor with conflicting results }\end{array}$ & $\begin{array}{l}\text { Available evidence does } \\
\text { not support consistent } \\
\text { and strong association } \\
\text { between breastfeeding } \\
\text { and ECC development. } \\
\text { Breastfeeding should } \\
\text { be continued as long as } \\
\text { mother and child wish }\end{array}$ & $\begin{array}{l}\text { No meta-analysis could be } \\
\text { undertaken }\end{array}$ \\
\hline $\begin{array}{l}\text { Ribeiro } \\
\text { and } \\
\text { Ribeiro } \\
(2004)^{2}\end{array}$ & $\begin{array}{l}\text { Review article exploring } \\
\text { association between } \\
\text { breastfeeding and ECC }\end{array}$ & $\begin{array}{l}\text { Inconsistent results found in studies } \\
\text { reviewed. } \\
\text { Studies reviewed of low quality }\end{array}$ & $\begin{array}{l}\text { No scientific evidence } \\
\text { to confirm breast milk } \\
\text { is associated with ECC } \\
\text { development }\end{array}$ & $\begin{array}{l}\text { Limited information given } \\
\text { regarding search strategy and } \\
\text { inclusion/ exclusion criteria. } \\
\text { No details provided of quality- } \\
\text { assessment process for articles } \\
\text { included in review }\end{array}$ \\
\hline $\begin{array}{l}\text { Vitolo et } \\
\text { al. }(2005)^{3}\end{array}$ & $\begin{array}{l}\text { Setting: Brazil. RCT } \\
\text { to assess impact of a } \\
\text { nutritional intervention } \\
\text { on infant health. Only } \\
\text { abstract written in English }\end{array}$ & $\begin{array}{l}\text { Based on the abstract, intervention } \\
\text { group had higher proportion of } \\
\text { exclusive breastfeeding at } 4 \text { and } 6 \\
\text { months and also of breastfeeding at } \\
12 \text { months. } \\
\text { Study reported a lower proportion of } \\
\text { children receiving the intervention } \\
\text { experiencing dental caries (RR, } 0.56 \text {; } \\
95 \% \mathrm{Cl}, 0.32-0.96 \text { ) at } 12-16 \text { months }\end{array}$ & $\begin{array}{l}\text { The nutritional } \\
\text { programmes may lead to } \\
\text { positive changes in infant } \\
\text { feeding behaviour and thus } \\
\text { improvements in health }\end{array}$ & $\begin{array}{l}\text { Detailed analysis of study not } \\
\text { possible as written in Portuguese. } \\
\text { Second paper } 4 \text { from this study } \\
\text { published in English provides } \\
\text { more detail on the feeding } \\
\text { practices promoted with regard to } \\
\text { breastfeeding, namely: avoiding } \\
\text { using bottles or breastfeeding } \\
\text { as pacifiers and to gradually } \\
\text { restrict either bottle feeding or } \\
\text { breastfeeding during the night. } \\
\text { Data from this study therefore cannot } \\
\text { be extrapolated to make statements } \\
\text { regarding effects of on-demand and } \\
\text { at-night breastfeeding beyond } 6 \\
\text { months on development of ECC }\end{array}$ \\
\hline $\begin{array}{l}\text { lida et al. } \\
(2007)^{5}\end{array}$ & $\begin{array}{l}\text { Setting: US. Secondary } \\
\text { analysis of cross-sectional } \\
\text { data obtained from 1999- } \\
2002 \text { National Health and } \\
\text { Nutrition Examination } \\
\text { Survey ( } n=1576 \text { children } \\
\text { of } 2-5 \text { years old). } \\
\text { Aim was to investigate } \\
\text { potential association } \\
\text { between breastfeeding } \\
\text { and other risk factors on } \\
\text { development of ECC }\end{array}$ & $\begin{array}{l}\text { Initial bivariate analysis demonstrated } \\
\text { that children breastfed for }>1 \text { year in } \\
\text { total were more likely to experience ECC } \\
\text { than children who were breastfed for } \\
<1 \text { year }(P<0.01) \text {. Subsequent Poisson } \\
\text { regression demonstrated that history of } \\
\text { breastfeeding or breastfeeding duration } \\
\text { of any time was not significantly } \\
\text { associated with dfs counts. Further } \\
\text { regression analysis demonstrated } \\
\text { that after controlling for confounding } \\
\text { factors, breastfeeding was associated } \\
\text { with a } 40 \% \text { reduced risk for ECC }\end{array}$ & $\begin{array}{l}\text { There is no evidence } \\
\text { from this analysis that } \\
\text { breastfeeding or its } \\
\text { duration are independently } \\
\text { associated with an } \\
\text { increased risk for ECC }\end{array}$ & $\begin{array}{l}\text { Cross-sectional data being used to } \\
\text { examine potential associations. } \\
\text { Data collected about feeding } \\
\text { history may be subject to recall } \\
\text { bias. } \\
\text { Confounding variables such as } \\
\text { patterns of breastfeeding, dietary } \\
\text { and oral hygiene habits not } \\
\text { adjusted for because of lack of } \\
\text { available data }\end{array}$ \\
\hline $\begin{array}{l}\text { Kramer et } \\
\text { al. }(2007)^{6}\end{array}$ & $\begin{array}{l}\text { Setting: Belarus. Cluster } \\
\text { RCT investigating effect } \\
\text { of an intervention to } \\
\text { promote breastfeeding } \\
\text { ( } \mathrm{n}=17046 \text { ). } \\
\text { Children followed up at } \\
6.5 \text { years to determine } \\
\text { effects of breast feeding } \\
\text { on dental caries }\end{array}$ & $\begin{array}{l}\text { Intervention arm of RCT had } \\
\text { substantially increased rates of any } \\
\text { breastfeeding at } 3,6,9 \text { and } 12 \\
\text { months. } 81.5 \% \text { of children had a } \\
\text { dental examination at } 6.5 \text { years. No } \\
\text { significant difference found in DMFT } \\
\text { between experimental and control } \\
\text { groups }\end{array}$ & $\begin{array}{l}\text { No reduction in caries } \\
\text { risk with prolonged and } \\
\text { exclusive breast feeding }\end{array}$ & $\begin{array}{l}\text { Studies used experimental group } \\
\text { as a proxy for higher breastfeeding } \\
\text { rates so duration of breastfeeding } \\
\text { not known for those individuals } \\
\text { who developed caries and those } \\
\text { who did not. } \\
\text { Data on differences between } \\
\text { breastfeeding rates for groups } \\
\text { are only given for } 12 \text { months, so } \\
\text { inferences on effects of breastfeeding } \\
\text { beyond this age cannot be made. } \\
\text { Dentists recording caries were not } \\
\text { trained and calibrated. } \\
\text { Children were examined at } 6.5 \\
\text { years of age, when a significant } \\
\text { proportion had lost their } \\
\text { deciduous incisors which may lead } \\
\text { to underestimate of effects }\end{array}$ \\
\hline
\end{tabular}


fertility and postpregnancy weight loss. ${ }^{8}$ Current UK guidance recommends exclusive breastfeeding for the first 6 months of an infant's life and that breastfeeding should continue beyond this, along with appropriate types and amounts of solid foods. No upper age limit for cessation of breastfeeding is given (www.dh.gov.uk/en/Healthcare/ Maternity/Maternalandinfantnutrition/ index.htm)

The World Health Organization also advises exclusive breastfeeding for the first 6 months of life and recommends that it continue in addition to other suitable sources of nutrition for up to 2 years or beyond (www.who.int/features/qa/57/en/index. $\mathrm{html}$ ) although it is of note that the health benefits of continuation of breastfeeding for periods greater than 6 months in industrialised countries remain unclear. ${ }^{9}$

The incidence of breastfeeding has increased in all regions of the UK in recent years, ${ }^{10}$ but there has been change in the duration of women breastfeeding, with declines in duration seen in Scotland. ${ }^{10}$
The prevalence of infants being breastfed at 6 months of age in the UK was still only $25 \%$ in $2005,{ }^{10}$ but with national and international policies emphasising breastfeeding, it is likely that this figure will increase. It may, therefore, be appropriate for further highquality research to be undertaken to explore the relationship between prolonged breastfeeding and ECC.

\section{Clinical bottom line}

Given the proven health benefits of breastfeeding and the lack of consistent evidence linking breastfeeding to the development of ECC, dental professionals should support current recommendations for breastfeeding. Emphasis should be placed on promoting good oral hygiene practice from the time of eruption of the first tooth and advice to reduce the frequency and consumption of sugar-containing foods and drinks.

1. Valaitis R, Hesch R, Passarellia C, Sheehan D, Sinton J. A systematic review of the relationship between breastfeeding and early childhood caries. Can J Publ Health 2000; 91:411-417.
2. Ribeiro NM, Ribeiro MS, Breastfeeding and early childhood caries: a critical review. J Pediatr (Rio J) 2004; 80(suppl.5):S199-S210.

3. Vitolo MR, Bortolini GA, Feldens CA. Impacts of the 10 steps to healthy feeding in infants: a randomized field trial. Cad Saude Publica 2005; 21:1448-1457.

4. Feldens CA, Vitolo MR, Drachler ML. A randomized trial of the effectiveness of home visits in preventing early childhood caries. Community Dent Oral Epidemiol 2007; 35:215-223.

5. lida $\mathrm{H}$, Auinger $\mathrm{P}$, Billings RJ, Weitzman $\mathrm{M}$. Association between infant breastfeeding and early childhood caries in the united states. Pediatrics 2007; 120:879-886

6. Kramer MS, Vanilovich I, Matush L, et al. The effect of prolonged and exclusive breast-feeding on dental caries in early school-age children. Caries Res 2007; 41:484-488.

7. Bick $\mathrm{D}$. The benefits of breastfeeding for the infant. $\mathrm{Br}$ J Midwifery 1999; 7:312-319.

8. Kramer MS, Kakuma R. Optimal duration of exclusive breastfeeding. Cochrane Database Syst Rev 2002. issue 1.

9. World Health Organization, Unicef. Feeding and Nutrition of Infants and Young Children. Regional Publications, European Series. Geneva: WHO; 2003, no.87.

10. Bolling K, Grant C, Hamlyn B, Thornton A. Infant Feeding Survey 2005. London: Office for National Statistics; 2007.

Evidence-Based Dentistry (2008) 9, 86-88. doi:10.1038/sj.ebd.640603 